\title{
Truthmaker 原理はなぜ制限されるべきか
}

\author{
秋葉剛史
}

\begin{abstract}
Abstract. According to the "truthmaker maximalism", every true contingent proposition is made true by something in the world, called its truthmaker. Although at first sight the maximalism seems to be a natural position, it has serious difficulties, especially concerning negative truths. In view of this, many truthmaker theorists adopt some non-maximalist position. It is not clear, however, whether these non-maximalists are justified, since existing reasons to justify the non-maximalism are not good enough. In this paper, then, I shall propose a new reason for the non-maximalism, which consists in the observation that the maximalism cannot acknowledge the widely accepted view that certain inferences involving logical constants are valid in the properly logical sense.
\end{abstract}

我々が信じたり主張したりする命題のうち, あるものは真であり, 他のも のは真でない 1 . 我々の常識的な見方に従えば, 命題の真偽のこうした違い を「実在世界における根拠の有無」に訴えて説明することは極めて自然であ る. 例えば, 〈富士山の標高は $3,776 \mathrm{~m}$ である〉という命題は, 特定の地理条 件を自らの根拠としてもち，それによって真にされる. 反対に，〈剣岳の標 高は $3,776 \mathrm{~m}$ である〉は，そうした根拠を実在世界のうちに欠くことによつ て真理性を欠く。一般的に言つて, 命題 (少なくとも偶然的命題) の真偽は, 世界内に存在しそれを真理たらしめる存在者の有無によって決定されるとい う考えは, 我々の常識実在論的な真理観に深く根差したものだと言える.

このような意味での真理根拠は，現代形而上学において「真にするもの truthmaker」と呼ばれている（以下 “TM”と略す）。TMに関連して論じられ 
る話題は多岐に及ぶが ${ }^{2}$, そのなかの重要な問題の一つに,「どのような種類 の真理にTMを認めるべきか」というものがある. 一見すると, この問題に 対しては,「全ての偶然的真理がTMをもつ」という立場 (Truthmaker Maximalism. 以下「全面主義 ${ }^{3}$ ) ) が最も率直で自然な解答を与えているよ うに見える. だが，周知のように，全面主義には特に否定的真理に関して深 刻な困難があり，この立場を維持できる見通しは決して明るくない。実際， $\mathrm{TM}$ 概念に魅力を感じる論者の多くは, 全面主義を拒否し, より限定された 範囲の偶然的真理に対してのみ TMを認めるという立場（「非全面主義」）を とつている ${ }^{4}$. 私自身も, 結論としては非全面主義をとるべきだと考えるの だが, ここで問題はその理由である. というのも, 以下で見るように, 非全 面主義をとるための理由としてこれまで関連文献で提案されてきたものは, 決して満足の行くものではないからである.

このような事情を踏まえ，本稿で私は次の問いに答えることを目指す．す なわち，非全面主義という立場をとるためのよい理由はあるのか，という問 いである. 結論から言えば，そのような理由は実際あると私は答える，そし て簡単に予告しておけば, その理由とは,「全面主義をとると, 論理的に妥 当な推論に関する標準的な見解を拒否せねばならなくなるから」というもの である.

本稿の構成を示しておこう。 まず第 1 節では，以下で用いる基本的な概念 と仮定について説明した後で，全面主義を定式化し，この立場が抱える困難 を確認する. 次の第 2 節では, 非全面主義をとるための既存の理由が十分で ないことを示すと同時に, その検討作業を通じて, 求められる理由が満たす べき条件を取り出す，そして第 3 節では, 既存の理由に代わるよい理由とし て私が考えるものを提示する.

\section{1. 問題設定一全面主義とその問題点}

\section{1 準備作業}

TM という概念について改めて説明することから始めょう. 上述のよう に，TM とは，世界のうちに存在し真理の根拠となるような存在者である. このような存在者を要求したくなる背景には, 以下のような思考の筋道があ る ${ }^{5}$.まず，「真理」という性質は確かに命題の性質ではあるが，命題がそれ 単独で, それ自体としてもち得る内在的な性質ではない. むしろ真理は, 命 題が他の何かとの関係に立つことではじめてもち得る関係的な性質である. では，何との関係か．我々の常識実在論的な直観に従えば，その答えは明ら 
かである，すなわち，命題と関係してそれに真理性を付与するのは，実在世 界に存在している何らかの存在者に他ならない. 従って実在世界には, それ ぞれの真理を真理たらしめ, その真理性に責任を負つているもの, 言い換え れば，その「存在論的根拠」となるような存在者がなくてはならない。

本稿では, 各種の命題の TMはどのような存在者なのかという問題には立 ち入らないが, TM概念の内実をより明確にするためにも, 典型例として通 常認められているものをいくつか挙げておくことは有益だろう. 例えば, 〈松井秀喜が存在する〉という命題は, 松井秀喜本人を TMとしてもつと考 えられる. というのも, この命題はまさに松井秀喜の存在によって真理たら しめられていると言えるからである. また, 〈この机は白い〉という命題が 真である場合, その TM として通常考えられるのは, この机が白いという事 実や，この机の白さトロープといつた存在者である.

では，命題とTMの間の「真にする」という関係は，より正確にはどのよ うに理解されるべきか. この点については多くの論争があるが，本稿ではそ れには立ち入らず，標準的に認められている次の「必然化条件」だけを仮定 する ${ }^{6}$ :

( $\mathrm{Nec})$ ぞんな命題 $\mathrm{P}$ と対象 $\mathrm{e}$ についても, eが $\mathrm{P}$ 真にする $\Rightarrow \square(\mathrm{e} か ゙$ 存在する $\rightarrow \mathrm{P}$ は真である)

つまりこれによれば，ある命題を真にする存在者 $(=\mathrm{TM})$ は, 最低限, そ れが存在する全ての可能世界で当の命題が真であるようなものでなくてはな らない．この条件を仮定する理由は，そもそも TMの概念が，真理の存在論 的根拠という考えを捉えるためのものだつたという点にある. というのも, 真理の「根拠」であり得るためには, TMは少なくとも, その存在によって 当の命題の真理を保証できるものでなくてはならず, 逆に, 存在しながらも 当の命題が偽である可能性を残すような存在者は,「根拠」の名に值しない はずだからである．またこの必然化条件により，例えば，この机は，〈この 机は白い〉の TM候補から除外されることには注意しておこう。なぜなら, この机が存在しながらも（例えば黒く塗られることで）, 上の命題が偽であ ることは十分可能だからである.

\section{2 全面主義}

本稿の主題である「全面主義」に話を移そう，そのためには，次の「TM 原理」を先に見ておくのがよい? 


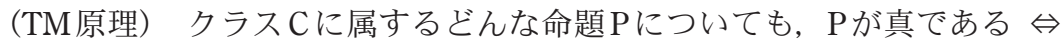
ある対象 $\mathrm{e} か ゙$ 存在し, eはPを真にする

つまり TM原理によれば，特定のクラスCに属する全ての真なる命題は，何 らかのTMによって真にされる.ただしここで注意すべきは, 「真理根拠と してのTM」というもともとの発想からして，この原理は非対称的な説明関 係を主張するものとして読まれるべきだという点である. すなわち TM原理 は, 単に, ある命題のクラスにおいては, 真なる命題と TMをもつ命題の外 延が二致する，という主張として理解されるべきではない。 むしろ TM原理 は, あるクラスに属する命題が真であるのは, まさにそれが TMをもつが故 にであり，その真理性はそれがTMをもつことから説明される（が，その逆 は成り立たない), という主張として理解されるべきである.（この点は 3 節 において重要となる.)

ただし，上記の「TM原理」は正確に言えば図式であり，その「クラス C」 をどう特定するかに応じて, TM原理にはいくつかのバージョンが存在する ことになる．そして，以下で主題となる「全面主義」とは，そのクラスCを 「全ての偶然的命題から成るクラス」と特定し, 次のように主張する立場で ある ${ }^{8}$ :

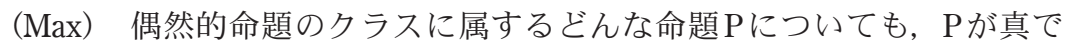
ある $\Leftrightarrow$ ある対象eが存在し, $\mathrm{e}$ は $\mathrm{P}$ 真にする

すなわち全面主義によれば，全ての真なる偶然的命題は何らかのTMをも ち，その真理性はTMの存在によって説明される.

この全面主義という立場は, TM原理のそもそもの背景と動機を踏まえれ ば，一つの自然な立場として理解できる，上で見たように，真なる命題は $\mathrm{TM}$ を必要とするという考え（つまり TM原理）は，「真理は実在世界のうち に根拠をもつ」という常識実在論的な直観からその動機を得ている.よつ て，TM原理は，この直観が妥当であるちょうどその限りにおいて適用され るべきだと考えるのは自然である．もちろん，真理のうちには必然的真理 (特に分析的真理) と呼ばれるものもあり, それらまでもが世界のうちに TMをもつと主張するのは無謀かもしれない（例えば〈全ての寡婦は既婚者 である〉は世界が何を含んでいようと真だろう) 9 。だが, ひとたび話を偶然 的真理の領域に限れば，上の実在論的直観は方の全域におい妥当性を保持 できるように見える．というのも，一般に「偶然的真理」とは，まさに実在 
世界の実際のあり方に根拠づけられて真であるような命題の別称のはずだか らである.このような事情により, TM原理の適用範囲を偶然的命題一般と する全面主義は, 確かに一つの自然な立場だと言える.

\section{3 全面主義の困難}

しかし周知のように, 全面主義を維持するのは並大抵のことではない。こ の立場に関して特に問題視されているのは, 否定的真理に関する困難であ

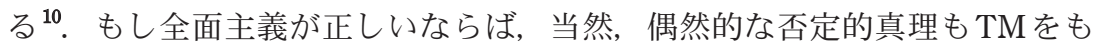
つことになる．だが，〈この机は青くない〉や〈ドラゴンは存在しない〉な どの否定命題の TM とはどのようなものだろうか. この問いに対しては, こ れまでいくつかの解答が提案されてきたが, ぞれも満足なものとは言い難 い.ここでの目的はそれらの解答に決定的な反論を与えることではないが, 少なくとも, それらを維持するのが決して容易でないことは確認しておこ う.

第一に, 否定的真理 $\neg \mathrm{P}$ の TM は, 対応する肯定命題 $\mathrm{P} の$ 真理と非両立的 な何らかの存在者だという見解がある.これに従えば，例えばくこの机は青 くない〉のTMは, 〈この机は青い〉の真理と非両立的な存在者（e.g.この机 は白いという事実）である。だが，この見解には一般性に関する問題があ る. というのも, この見解が通用するのは, 対応する肯定命題の真理と両立 しない存在者を確保できる場合（色や形の確定的性質の帰属が典型例）に限 られるが, 〈ドラゴンは存在しない〉といった否定存在命題の場合にもそう した存在者が確保できるかどうかは, 全く明らかでないからである.

第二に, 否定的真理 $\neg \mathrm{P}$ の TMは, 「Pでないという事実」などの否定的存 在者だという見解がある. だがこの見解には, 否定的存在者なるものについ て指摘される一般的な問題（その本性の神秘性, 因果的効力の欠如等）に加 えて, 次のような難点もある. もしつ $\mathrm{P} の \mathrm{TM}$ が何らかの否定的存在者であ

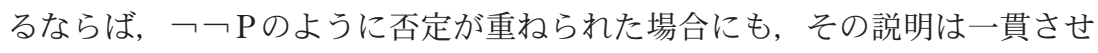
られるべきだろう。よって，例えば〈シマウマは存在しないということはな い〉という二重否定命題は, 何らかの仕方で否定性を二重に含んだ存在者を TM としてもつはずである. だが, ごく常識的に考えて, 〈シマウマは存在 しないということはない〉を真にするのは現実に存在するシマウマたちであ り,「否定性を二重に含んだシマウマ」のような奇妙な存在者ではない.

第三に, 否定的真理の TMは, 「この机は白い」や「あの空は割れている」 といつた通常の（一階の）事実に加え，「それらが一階の事実の全てである」 という文階の事実を合わせたものだという見解がある，これによれば，否定 
的真理 $\neg \mathrm{P}$ は，対応する $\mathrm{P}$ 真にするような事実が「一階の事実の全て」に 含まれていないことによって真となる．だがこの見解の問題は，ここで言わ れる二階の事実なるものが，それ自体偽装された否定的事実に過ぎないこと である.つまり，しかじかのものが一階の事実の全てだという事実は，それ 以外の何ものも一階の事実でないという否定的事実に他ならない，従って， この見解は否定的存在者について指摘される一般的問題（その本性の神秘 性, 因果的効力の欠如等) を解決することなく, それらをそのまま抱え込ん でいる.

以上のように，否定的真理の TMに関するこれまでの解答は，控え目に 言っても決して満足の行くものではない。従って, 現段階においては, 全面 主義を擁護できる見通しは決して明るいものとは言えない. こうした状況を 受け，TM概念に魅力を感じる論者の多くは，全面主義を放棄し，TM原理 をより制限された形で採用する立場（以下，「非全面主義」吕）を選択してい る ${ }^{12}$.つまり，非全面主義によれば，TM原理は偶然的真理一般について妥 当するものとしてではなく, そのなかの特定の種類のもの（例えば肯定的真 理）だけに妥当するものとして受け入れられるべきなのである.

だが，ここは立ち止まりどころである，というのも，事実亡して非全面主 義をとる者がいることは, 当然, その選択が正当な理由からなされているこ とを意味しはしないからである. むしろ以下で見るように, 非全面主義をと るための理由としてこれまで挙げられてきたものは, 実際は明らかに不十分 である.だが，もしこの選択肢が絶たれているのだとすれば，TM概念を支 持する者は例外なしに全面主義者であらざるを得ないことになり, 従って, 上で見たような困難をも引き受けざるを得ないことになる．つまり TMの概 念は，その直観的な訴えと一見したところの無害さにも拘らず，実はそう気 楽に採用してよいものではないことになる。では果たして, 非全面主義に正 当な理由を与えることは不可能なのだろうか. また，もし可能ならば，それ はどのような理由であり得るだろうか。本稿の以下の部分では，これらの問 題に対する答えを探つていこう.

\section{2. 非全面主義をとるための既存の理由}

我々が求めているのは, 全面主義を捨て, 非全面主義をとるためのより理 由である，本節では，そのような理由として関連文献で提案されている二つ の候補を取り上げ，それらが十分でないことを示す。この結論自体は否定的 なものだが，本節の検討作業は肯定的な意義ももっている．なぜなら，この 作業を通じて, 非全面主義をとるための理由がどのようなものでなくてはな 
らないか，その条件を明らかにできるからである。

\section{1 全面主義は単にもっともらしくないという理由}

非全面主義をとるための理由として, 最初に思いつかれるのは以下のよう なものかもしれない ${ }^{13}$. 非全面主義をとるべきなのは, ごく単純に，TM原 理が成り立ちそうにない種類の命題（例えば否定的命題）があるからであ る.このことは, ただそれだけで, 非全面主義をとるための十分な理由に なつている. なぜなら, 反例と思われるケースがあるから主張の範囲を制限 することは，哲学でも日常生活でもごく普通に行われており，そこにそれ以 上の理由は必要ないからである。例えば,「あることをするというどんな約 束も，そのことをする義務を生じさせる」と主張する人（A氏とする）がい るとしよう。このA氏は，例えば銃で脅されて交わした約束や，催眠術にか けられて交わした約束などのケースに思い至った結果, それらのケースを除 外するため自分の主張の範囲を制限しようとするかもしれない.だが通常 我々は，そのような制限に特別な理由を与えるよう A氏に要求したりはしな い.これと同様に，TM原理を無制限に主張しようとしていた人が，否定的 真理のようなケースに思い至った結果, 自分の主張の範囲を制限しようとす る場合にも, そのためのさらなる理由などは必要ない.

このような考察は一見もつともらしいが，これは非全面主義をとるための よい理由とはならない。単に「しかじかのケースではTM原理は成り立ちそ うにないから」というだけの理由でTM原理を制限することは, 何の原則も なしに全面主義から撤退を始めることである。しかし，こうした場当たり的 な対応はここで許容されるべきでない.というのも，原則なき撤退には原則 的な終止点もないのだから，ひとたび上のような理由から TM原理を制限し 始めたならば，その制限をどこかで止めることは難しくなるからである。 つ まり, 他の種類の命題についても, そのTMの候補が疑問視されるたびごと に，その種の命題を TM原理の範囲から外していかねばならなくなる.だが これは, TM原理の全面的な放棄（あるいはよくても非実質化）へと通じる 屝を開くことである. いま求められているのは, 制限された形であれ, あく まで $\dot{\mathrm{TM}}$ 原理を保持するための理由なのだから，TM原理一般の放棄につな がる上のような理由は安易に採用されるべきでない.

上で挙げられた約束と義務の例も, ここでの助けにはならない.つまりそ の例も，ある主張の範囲を制限したいとき，単に「反例と思われるケースが あるから」という理由に訴えてよいことを示すものではない. 確かに我々 は, 脅迫や催眠術のケースに思い至つて約束と義務の結びつきを制限する A 
氏に対して, それ以上の理由を求めないかもしれない. しかし, 我々がここ で理由を求めないのは, 単にそれらのケースが反例に見えるからというより も, むしろ我々が A氏の行う制限の背後に，すでに何らかの原則的理宙を見 て取っているからだと思われる. その理由とは例えば,「自由な決定に基づ かない約束行為は義務を生じさせない」といつたものである. つまり我々 は, 脅迫などのケースを除外する A氏の振舞いを, (暗黙のうちにであれ） こうした理由に則ったものと見なすからこそ, 彼にそれ以上の正当化を要求 しないのだと考えられる.

以上から，いま求められている理由が満たすべき条件の一つが明らかにな る.すなわち，非全面主義をとるためのよい理由は，TM原理をどのような 範囲へと制限すべきかについての何らかの原則を含んでいなくてはならな い.

\section{2 論理定項は表象しないという理由}

しかし，そのような原則を含んだ理由は，案外簡単に見つかるかもしれな い. その手がかりとなり得るのは, ウィトゲンシュタインに由来する「論理 定項は表象しない」という考えである (Wittgenstein (1922: 4.0312)) ${ }^{14}$. こ の考えは，以下のように全面主義を拒否するための理由へと展開できる．ま

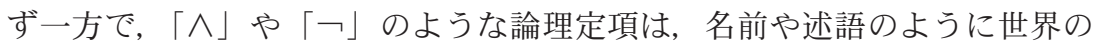
部分（個体や性質・関係）を表象するのではない，という主張はもっともら

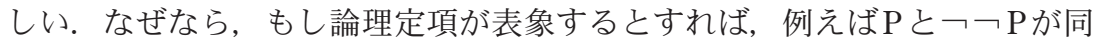
じ事物に関わつていることはあり得ないことになる（論理的複雑性を異にす るため) が, この二つの命題が同じ事物に関わつているという考えはむしろ 自然だからである（1.3のシマウマの例を参照）。だが他方で, 全面主義は, まさに論理定項が表象機能をもつことを要求しているように見える. 例え

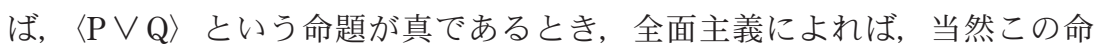
題にも固有の TMが存在する. しかし, そのTMはどのような存在者だろう か. その答えは, 「PのTMとQQTMを構成要素とし，それらが「V」の表 す仕方で結合されてできた複合体」というものにならざるを得ないだろう. だが,これはまさに「V」に表象機能を認めることである.このように， 「論理定項は表象しない」という主張は全面主義を拒否するための十分な理 由になるように見える.

この理由は, 上で見た「TM原理の制限範囲に関する原則」を含んでい る. なぜなら, この理由は, 論理定項に表象機能を認めないことで, 「TM 原理は, 論理定項を含まない命題のクラスだけに適用されるべきである」と 
いう原則を生み出す（結果, いわゆる「論理的原子論」を動機づける）から である.

しかし上の主張は, 別の観点から見て, 非全面主義をとるための理由とし て十分でない。 というのも, 実はこれによっては, 全面主義の基本主張 （Max）は拒否できないからである. 確かに, 論理定項は表象しないという 主張は, 特定のバージョシ்全面主義を拒否する理由にはなる. そのバー ジョンとはつまり, 論理的に複雑な真理の各々に対して, それと同じだけ複 雑な内的構造をもった TMを想定するような単純な夕イプの全面主義であ る. だが問題は, 全ての全面主義者がこうした単純な描像をとる必要はな く, 実際そうしてもいないことである. 例えば，代表的な全面主義者 D. M.アームストロングは, むしろ明示的にこうした描像を拒否している ${ }^{15}$. 彼 によれば，例えば〈P $\vee \mathrm{Q}\rangle$ の TMとして，「選言的事実」といった複合体を 想定する必要はなく, この命題の $\mathrm{TM}$ という役割は単に $\mathrm{P} の \mathrm{TM}$ か $\mathrm{Q}$ の $\mathrm{TM}$ のいずれかによって果たされる. また, 否定命題 $\neg \mathrm{P} の \mathrm{TM}$ としてアームス トロングが考えるのも, 否定詞「つ」が表象する構成要素を含んだ複合体な

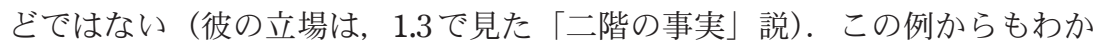
るように, ある種の全面主義者にとつては, 論理定項は表象しないという主 張を受け入れることには何の問題もなく, この主張は, 全面主義の（Max） に何らかの特殊な想定を足さない限り問題を引き起こさない. よって上の主 張は, 全面主義を拒否するための理由にはならず, 従って, 非全面主義をと るための理由にもならない.

以上の議論より, 非全面主義をとるためのよい理由の条件として, 新たに 次の点を取り出せる. すなわちそのような理由は, (Max) それ自体から生 じる困難を突き, 全面主義一般の拒否を促すようなものでなくてはならな $\omega^{16}$.

\section{3. 非全面主義をとるためのよい理由}

前節では，非全面主義をとるための理由としてこれまで提案されてきたも のが十分ではないことを見た．本節の目的は，これらに代わるよい理由を提 示することである. 私が以下で提案する理由は, 先に $2.2 て ゙$ 見たものと同 様, 論理定項のはたらきに関わるものだが, それとは異なる強調点をもつ.

すなわち, 2.2 で強調されたのが論理定項の表象機能の有無だったのに対 し, ここで見る理由は, 論理定項の「真理関数性」という特徵に焦点を当て るものである. 以下では, まずその問題の理由を提示した上で (3.1), それ に対する可能な反論に応答する (3.2-3). 


\section{1 全面主義は論理的真理関数に関して問題を抱える}

以下で示したいのは，全面主義を認めると，通常は「論理的な真理関数」 として認められている操作を, そのようなものとして認めることができなく なる, ということである.

まずは連言についてこのことを見てみよう. 連言は真理関数的な命題構成 操作であるという主張には, 任意の命題 $\mathrm{P}$ と $\mathrm{Q}$ にいて, 次の推論を論理的 に妥当なものとして認めることが含まれている：

（C） $\mathrm{P}$ が真であり，かつ， Q が真である $\Rightarrow \mathrm{P} \wedge \mathrm{Q}$ が真である

ここで,「(C) は論理的に妥当な推論である」ということが何を意味してい るかを確認することは重要である. それが意味しているのは, (C) の前件 が成り立つときには，世界が他の点でいかなる方方方をしていよう之も， (C) の後件が成り立つことが無条件に保証される，ということである．こ の考えは，いわば連言という操作の理解の一部を構成するものとして標準的 に受け入れられており, 実際極めて否定し難い.

だが，全面主義をとるならば，（C）をいま言った意味で妥当な推論とし て認めることができなくなってしまう。 そのことを示すため, 全面主義者 は, 上の（C）をどのような推論として理解しなければならないかを考えよ う．Pと Qが偶然的命題であるとき，全面主義の（Max）に従えば，（C）の 前件と後件は，それぞれ次が成り立つことに存し，その限りで成り立つ：

$\left(\mathrm{C}_{1}\right)$ ある対象 $\mathrm{e}_{1}$ が存在し, $\mathrm{e}_{1}$ は $\mathrm{P}$ を真にし, かつ, ある対象 $\mathrm{e}_{2}$ が存在 し, $\mathrm{e}_{2}$ は Qを真にする.

$\left(\mathrm{C}_{2}\right)$ ある対象 $\mathrm{e}$ が存在し, $\mathrm{e}$ は $\mathrm{P} \wedge \mathrm{Q}$ を真にする.

そして, (C) の前件と後件がそれぞれ $\left(\mathrm{C}_{1}\right)$ と $\left(\mathrm{C}_{2}\right)$ に存するとされる以 上, 全面主義によれば, (C) という推論の妥当性は, 次の原理（要する に, $\left.\left(\mathrm{C}_{1}\right) \Rightarrow\left(\mathrm{C}_{2}\right)\right)$ の妥当性に依存し, それによってはじめて保証されるも のとして理解されねばならない：

（C*）（ある対象 $\mathrm{e}_{1}$ が存在し, $\mathrm{e}_{1}$ は $\mathrm{P}$ 真にし, かつ, ある対象 $\mathrm{e}_{2}$ が存在 し, $\mathrm{e}_{2}$ は $\mathrm{Q}$ を真にする） $\Rightarrow$ ある対象 $\mathrm{e}$ 名存在し, $\mathrm{e}$ は $\mathrm{P} \wedge \mathrm{Q}$ を真に する 
しかしながら, 推論（C）の妥当性をこのような原理に依存させることは, すでにして，(C) が論理的に妥当な推論だという考えを放棄することであ る．説明しよう，まず，(C*) は明らかに，世界のあり方についての実質的 な形而上学的主張である. つまり $\left(\mathrm{C}^{*}\right)$ は, 「全てのxについて $\mathrm{x}=\mathrm{x} 」 や$ $\lceil\mathrm{P}$ ならば, $\mathrm{P} \vee \mathrm{Q}\rfloor$ といっ主張とは異なり, 世界に何がどのように存在し ようとも成り立つような（空虚な）主張ではない。従って，この原理に推論 （C）の妥当性を依存させるということは，この推論は，世界が (C*) が主 張するような特定市方方をしてい方が故に，また市限方穴妥当だ， と言 うことに等しい.だがこれに対し，上でも確認したように，(C) が論理的 に妥当であるという考えによれば，(C) は世界の実質的なあ方方に関わら す，無条件に成り立たなくてはならないのである ${ }^{17}$.

同様のことは否定についても言える. すなわち，一方で我々は，任意の偶 然的命題 $\mathrm{P}$ ついて次の推論を論理的に妥当なものと認めている :

（N） Pが真でない $\Rightarrow \neg \mathrm{P}$ が真である

だが再び，全面主義は（N）の妥当性を次の原理に依存させることになる：

$\left(\mathrm{N}^{*}\right)$ （どんな対象eについても，eが $\mathrm{P}$ 真にすることはない） $\Rightarrow$ ある 対象eが存在し, $\mathrm{e}$ は $\mathrm{P}$ を真にする

明らかに, 先の $\left(\mathrm{C}^{*}\right)$ と同様, この原理 $\left(\mathrm{N}^{*}\right)$ も世界のあり方についての 実質的な主張である. 従って全面主義者は, 標準的見解に反して, (N) と いう推論の妥当性は $\left(\mathrm{N}^{*}\right)$ という論理外の原理に依存すると主張せざるを 得ない.

いつたんまとめておこう. 非全面主義をとるためのよい理由として本節で 提示したのは, 「全面主義を受け入れると, 論理定項を含んだある種の推論 に認められるべき論理的妥当性を認められなくなるから」というものであ る. この理由は, 非全面主義をとるための理由に関して前節で取り出した二 つの条件を満たしていると考えられる．第一に，本節で提示された理由は， TM原理の制限範囲に関する原則を含んでいる. というのも, 論理的に妥当 な推論に関する上述の問題は, 専ら論理的に複雑な命題に TM 認めること から生じたものであり, その問題を避けるため, TM原理の適用範囲を論理 的に単純な命題に限るという道が自ずと示唆されるからである. 第二に, 本 節で提示した理由は，全面主義の一般的な拒否を迫るものになっている．な 
ぜなら，2.2で見た理由（論理定項は表象しない）とは異なり，本節の理由 は，全面主義の基本主張（Max）それ自体から生じる困難を突くものだから である.

\subsection{TMを世界全体とする立場は逃げ道にならない}

だが，話はここで終わらない。というのも，直前で見た二つ目の条件に関 しては, いまだ反論の余地があるように思われるからである. その反論と

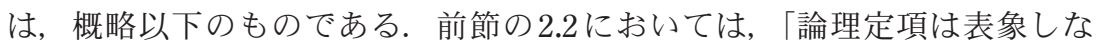
い」という主張は, 非全面主義をとる理由として十分ではないと論じられて いた. そして, その際持ち出されていた論拠は, 「この理由は, 全面主義の 立部のバージョシしか排除できないから」というものであった. これは裏を 返せば，ある理由が全面主義の何らかのバージョンを排除できずに残すなら ば，それは非全面主義をとる理由としては十分でないということである．だ

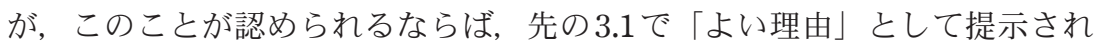
たものも，同じ論拠から不十分であることになる. なぜなら, 以下で見るよ うに，ある特定のバージョンの全面主義を採用しさえすれば， 3.1 で指摘さ れた問題は生じなくなるからである.

私は以下で，この反論は実際には成り立たないと論じるが，まずは反論の 中で言われる「特定のバージョンの全面主義」を見ておこう。 それは，全面 主義の基本主張（Max）に次を加えたものである（以下，「W型全面主義」 と呼ぶ) : ${ }^{18}$

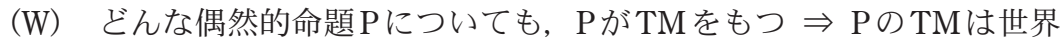
全体である

つまりW型全面主義によれば，全ての偶然的真理は，単に何らかのTMに よって真にされるというだけではない。むしろ偶然的真理は全て，世界全体 という唯一のTMによって真にされるのである.

先の 3.1 で全面主義の困難とされた点を思い出そう。それは, 全面主義を 受け入れると, 論理的に妥当なはずの推論 $(\mathrm{C})$ や $(\mathrm{N})$ の妥当性が, 論理外 の原理 $\left(\mathrm{C}^{*}\right)$ や $\left(\mathrm{N}^{*}\right)$ の妥当性に依存していることになってしまう, という ものだった．だがここで，W型全面主義者は，次のように反論し得る（以 下二つの段落では反論者を代弁する).

$\mathrm{W}$ 型全面主義にとっては, 3.1 の議論は深刻な問題を提起しない。確かに, （Max）に従えば,（C)や $(\mathrm{N})$ という推論は, $\left(\mathrm{C}^{*}\right)$ や $\left(\mathrm{N}^{*}\right)$ という原理が成 
り立つ限りにおいてのみ妥当である. だがここで, それら推論が依存する原 理 $\left(\dot{\mathrm{C}}^{*}\right) \dot{\mathrm{C}}\left(\dot{\mathrm{N}}^{*}\right)$ 自体が無条件的な妥当性をもつとしたらどうか. もしそれ が成り立つならば, 推論 $(\mathrm{C})$ や $(\mathrm{N})$ にも, 再び無条件的に妥当という地位 を与え直してやることができるだろう，そして注目すべきことに，W型全 面主義においては, 実際ある意味で $\left(\mathrm{C}^{*}\right)$ と $\left(\mathrm{N}^{*}\right)$ の無条件的妥当性が認め られる. なぜなら，この二つの原理は，W型全面主義の基本主張 (W) から 導かれるからである.（もちろん，「ある意味で」と断ったように，ここで二 つの原理に認められる「無条件性」は, 確かに(W) という仮定に相対的な ものである. だが, いま問題なのはあくまでも, 全面主義の何らからバ二

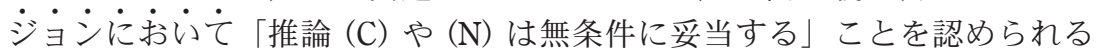
かどうかなのだから，この点は障害にならない。つまり, 実際に $(\mathrm{W})$ から $\left(\mathrm{C}^{*}\right)$ と $\left(\mathrm{N}^{*}\right)$ が導けさえすれば, 推論 $(\mathrm{C})$ や $(\mathrm{N})$ の無条件性はW型全面主 義で認められていると主張でき，それこそがいま必要なことの全てである.）

実際, $\left(\mathrm{C}^{*}\right)$ と $\left(\mathrm{N}^{*}\right)$ は以下のように $(\mathrm{W})$ から導かれる. まず $\left(\mathrm{C}^{*}\right)$ につ いてこれを見るため, 二つの命題 $\mathrm{P}$ と $\mathrm{Q}$ をれぞれ真にする対象 $\mathrm{e}_{1}$ と $\mathrm{e}_{2}$ が存 在するとしよう ( (C*) の前件)，このとき，(W) に従えば，それらの対象 $\mathrm{e}_{1}$ と $\mathrm{e}_{2}$ は, ともに世界全体でしかあり得ない。 よってこのとき, ある単一の 対象（=世界全体）が存在し，それが $\mathrm{P}$ とを共に真にしていることになる ( ( $\left.\mathrm{C}^{*}\right)$ の後件). また, $\left(\mathrm{N}^{*}\right)$ についても次のように論じられる. どんな対象 も $\mathrm{P}$ 真にすることはないと仮定しょう $\left(\left(\mathrm{N}^{*}\right)\right.$ の前件 $)$ こののこは, （W）に従えば，世界全体が Pを真にしないことと同じである. さらにここ で,「世界全体」という存在者がもつある特殊性に注目しよう。それはつま り，世界とは定義上（あるいは本質上）, 任意の偶然的命題についてその肯 定と否定のどちらが真かを決定してくれるような存在者だというものであ る. この考えは，（もちろん疑うことは可能だが）十分信ずるに值するもの

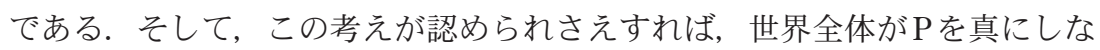
いという目下の仮定から, 世界全体は $\neg \mathrm{P}$ 真にするということ, 従って, $\neg \mathrm{P}$ 真にするものが存在すること（ $\left(\mathrm{N}^{*}\right)$ の後件）が導かれる.

さて, 以上のような反論に対してはどのように応じるべきだろうか。一つ 考えられるのは, $(\mathrm{W})$ から原理 $\left(\mathrm{C}^{*}\right)$ と $\left(\mathrm{N}^{*}\right)$ を導こうとする直前の論証を 疑うという道である. だが，ここでは単純に全面主義に対して上の論証を認 めておくことができる.なぜなら，いずれにせよ全面主義は苦境を逃れるこ とはできないからである. 確認しておくと, 上の反論の要点は, もし仮に

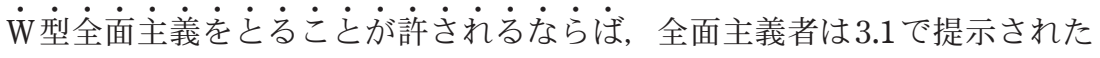
困難を回避できる, という条件付きのものに過ぎない.つまり，上の反論が 
有効であるためには,「W型全面主義をとることは許される」という条件が 満たされねばならない，だが，まさにこの条件こそ疑われるべき点である. というのも, すぐ下で見るように，この立場からは到底受け入れ難い様相的 帰結が生じるからである ${ }^{19}$.

そのことを示すための任意の例として，いま現実に，私の目の前に机が一 つあるとしよう. そして〈この机は污れている〉という命題が真だとしよ う、W型全面主義に従えば，この命題を真にするのは，私たちの住む現実 世界@である ${ }^{20}$. だが, この命題のTMであるためには, 世界@はどのよう なものでなくてはならないのか.ここで思い出すべきは, 「真にする」とい う関係についての「必然化条件」である $(1.1 の(\mathrm{Nec}))$. それによれば, 一般に, 対象 $\mathrm{e}$ 命題 $\mathrm{P} の \mathrm{TM}$ であるためには, e は最低限, それが存在す る全ての可能世界で Pが真であるようなものでなくてはならない. 従って, いまの文脈で言えば，世界@が存在する全ての可能世界において〈この机は 污れている〉は真である，ということをW型全面主義は認めなくてはなら ない.

もつとも,「世界@が他の可能世界において存在する」というのは確かに 聞き慣れない言い回しだろう。だが，通常の個体の場合と類比的に考えれ ば, この点に特別なことはない.すなわち, 例えばソクラテスが可能世界 $\mathrm{w}$ において存在することが，ソクラテスがその世界 $\mathrm{w} に$ 何らかの対応者をもつ

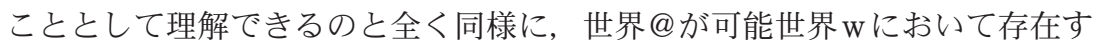
ることは, @が世界 $\mathrm{w}$ に何らかの対応者をもつこととして理解できる. そし てこれを踏まえると, W 型全面主義が認めねばならないものとして上で確 認した主張は, 次のように言い換えられることになる. すなわち，世界@の 対応者が存在する全ての可能世界において, 〈この机は污れている〉は真で ある、と、

だが，これはすでに著しく反直観的な帰結である．そのことを示すには， さらに二つの点を確認すればよい. 第一に, 対応者と事象関与的 (de re) 可 能性に関しては, 次の原則が成り立つ. すなわち一般に, 対象aが「可能的 にFである」という性質をもつことは, aの何らかの対応者が Fであること と同值である（例えば, ソクラテスが美男であり得たことは, 彼の何らかの 対応者が美男であることと同值である). 第二に, 前段落までで確認した W 型全面主義の主張は, 世界@のどんな対応者も,〈この机は污れている〉が 真であるような世界に存在する, という主張と同值である. これはさらに言 い換えれば，世界@のいかなる対応者も，「〈この机は污れている〉が偽であ るような世界に存在する」という性質をもたない，ということである，そし 
て，以上の二点を踏まえると，W型全面主義は結局，次のことを主張してい ることになる.すなわち，現実世界@にとって，「〈この机は污れている〉が 偽であるような世界に存在する」ことは, その可能なあり方の一つでさえな い, ということを. より直観的に言えば，これが意味するのは，我々の住む 現実世界は, そのうちでこの机が污れていないようなものではあり得なかつ た, ということである. しかし, 一体なぜ我々の世界の可能的なあり方がこ のような仕方で制限されていなければならないというのか。 これは理解に苦 しむ結論だろう.

こうした結論の信じ難さは，上の議論が任意の対象と性質についてのもの だったことを思い出せば，さらに鮮明になる，つまり，上の結論は完全に一 般化され，W型全面主義からは次のことが導かれる，すなわち，現実に成 り立っている全ての偶然的真理 Tについて, 「現実世界は, Tが真でないよ うなものではあり得なかつた」ということが導かれる，これはつまり，現実 世界は, 現にそうである仕方と微塵たりとも異なることはできなかった, と いうことである．だが，ごく普通に考えて，現実世界が現にそうであるのと 異なっていたことなどいくらでも可能である. 例えば, 私の眼前の机は污れ ていなかったかもしれないし，ナポレオンは現実より一センチだけ背が高 かつたかもしれない.こうした全ての様相的直観がW型全面主義において は否定されざるを得ない以上，ここでとるべき道はもはや明らかだろう。つ まり，これら全ての様相的直観と引き換えに，W型全面主義を受け入れる 余地はない.

以上で, 3.1 の理由に対する全面主義からの反論が成り立たないことが示 された.つまり，全面主義には（W）を採用することで論理的に妥当な推論 に関する困難から逃れるという道は閉ざされている. よって, 全面主義はや はり拒否されるべきである.

\section{3 制限つき TM原理と実在論的直観}

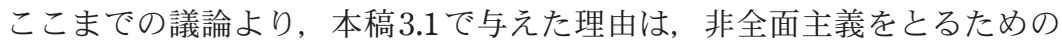
理由に対して 2 節で課された二つの条件を満たしている，と結論できる．だ が, この理由がそのための十分な理由だと主張できるためには，もう一つ解 決すべき課題がある. その課題とは, 全面主義を拒否して制限つき TM原理 を採用することの動機に関する以下のような一般的な疑念に応えることであ $ろ^{21}$.

その疑念の内容を述べるため，まずは 1 節で全面主義が一つの自然な立場 として描かれた過程を思い出そう。その出発点は，(a) 真理は実在のうちに 
根拠をもつ，という実在論的直観であつた。 そして全面主義という立場は, この直観を次の二つの主張によつて精緻化することで導かれていた. すなわ ちその主張とは, (b) 実在のうちに根拠をもつのは, 偶然的真理一般であ る, (c) 真理が実在のうちに根拠をもつとは, それがTMをもつことに他な らない, という二つである. しかし一方で, 本稿のこれまでの議論によれ ば，全面主義は拒否されねばならず，従って，上の（a)- (c) のどれかが拒 否されねばならない，だがこのうち，（a）と（b）は共に，我々の健全な常識 に強く訴えるものであり, 簡単に拒否できるものではない. よって結局, 本 稿の議論に従えば,「真理の根拠」と「TM」を同一視する (c) が拒否される ベきだということになる．しかしながら，これは本稿の議論方針にとつて極 めて望ましくない状況であるように見える. なぜなら，本稿で求められてい

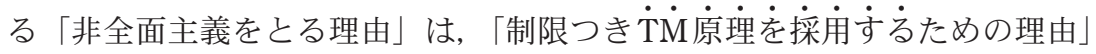
であるのに対し，本稿1節において TM原理は，（a）の直観をまさに (c) に 基づいて（根拠と TMの同一視によって）解釈することにより動機づけられ ていたからである、つまり，本稿のこれまでの議論は，（c）を拒否すること により，（a）の実在論的直観から $\mathrm{TM}$ 原理への動機づけの通路を塞いでし まっているように見える.

このような疑念に応えるためには，上記の（c）を採用する以外にも，(a) の実在論的直観から TM原理を動機づける方法がある, ということが示され ればよい，そして，そうした方法を与えることは，実際のところそれほど難 しくはない，結論から言えば，その方法とは，上の（c）に代えて次を採用 することである：(c') 真なる命題 $\mathrm{P}$ が実在のうちに根拠をもつとは, Pの真

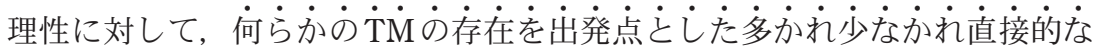
説明が存在するう்である.

この (c') には, 二つの重要な特徵がある. 第一に (c') は, 実在論的直観 （a）の適切な精緻化になっている. そして第二に，（c'）による精緻化のもと で見てみると, 直観 (a) は制限つき TM原理を動機づけるものとして解釈で きるようになる.

第一点目から見ていこう. いま問題の (c') は, 先の (c) と異なり, 真理 とTMの間の根拠づけ関係が間接的でもあり得ることを認めている. つまり (c')によれば,「真理が実在のうちに根拠をもつ」仕方のうちには, 〈aは F である〉のような論理的に単純な真理とそれを真にする TMの間に成り立つ ような, 直接的な根拠づけの関係だけが含まれる訳ではない。 むしろ (c') によれば,「真理が実在のうちに根拠をもつ」仕方のうちには, $\langle\mathrm{P} \vee \mathrm{Q}\rangle$ の

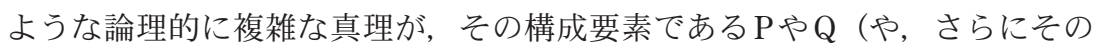


構成要素である $\left.\mathrm{P}_{1}, \mathrm{P}_{2}, \cdots, \mathrm{Q}_{1}, \mathrm{Q}_{2}, \cdots\right)$ を媒介して, 最終的に, TMによって直 接根拠づけられた原子的真理に基づいて決定・説明される, といつた場合も 含まれる.だが，真理の根拠づけがこのように間接的でありうることを認め たからと言って，それによって (c') が直観 (a) の害質を失わせているとい うことにはならない。 なぜなら，(c'）は依然として，「真理は，どれほど間 接的な仕方であっても, 最終的には実在世界の根拠たる TMに結びつけら れ，それに基づいて説明される」ということを要求しているからである22. このことを要求している以上，(c’）は，「真理は実在のうちに根拠をもつ」 という直観 (a) の内実に反するものではなく, その精緻化として十分適切で ある.

二点目は手短かに済ませよう。ここで重要なのは, 上の (c')により精緻 化されたものとして見てみると, 実在論的直観 (a) は結局, 真理の直接的説

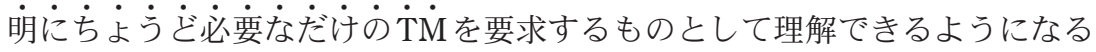
という点である. なぜなら，(c'）によれば，ある真理が実在のうちに根拠を もつためには, その真理に対して TMを起点とした説明を与えることができ れば十分なのであり, TMが果たすべき役割は, まさにそうした説明の起点 を提供することに存するからである. そして, 前段落でも示唆したように, 全ての真理の説明が TMの存在に直接訴えたものである必要はないというこ とは, 論理的に複雑な命題などのケースを考えれば明らかである. 従って直 観（a）は, （c'）を介することで, 制限つきTM原理を動機づけるものとして 解釈できるようになる.

\section{4. 結論}

全面主義を拒否し非全面主義をとるためのよい理由は存在するのか，する とすればそれはどのようなものか一これが本稿の問いだった. この問いに 答えるために私が提案したのは, 「全面主義を採用すると, 論理定項を含ん だある種の推論の論理的な妥当性を認められなくなる」という理由である. この理由は, 次の二つの意味でよい理由である. 第一に, この理由はTM原 理の制限範囲に関する原則を含夕, TM原理の全面的な放棄へと導く危険が ない. 第二に, この理由は全面主義という立場が受け入れ難いものであるこ とを一般的に示すものになっている. さらに, 非全面主義をとる理由のそも そもの存在可能性に関する疑念に対しても, TM原理の背景である実在論的 直観に全面主義とは異なる解釈を与えることで応えられる，以上から私は， 非全面主義をとるためのよい理由は（少なくとも一つ）存在する, と結論 する ${ }^{23}$. 
1. 本稿では真理の担い手は（非ラッセル的）命題だと仮定する. また，原則と して $\mathrm{P}$ という命題を「 $\Gamma \mathrm{P}>」$ と表記するが，煩雑さを避けるため「<」「>」を 省略することもある.

2. TM概念に関連する多様な問題は, Rami (2009) で概観されている.

3. “maximalism” の訳語としては「極大主義」の方が直訳に近いが, 問題になつ ているのがTM原理の適用範囲であることを考慮し「全面主義」とした.

4. Cf. Mulligan et al. (1984), Simons (1992).

5. Cf. Rodriguez-Pereyra (2005: 20ff.).ここで見るような仕方での TM 概念とTM 原理の動機づけには異議もある (cf.Dodd (2007)) が, この点の検討は他日を期 したい.

6. Cf. Armstrong (2004: 5-7), Rami (2009: 8-9).

7. しばしば「TM原理」としては, 本文の（TM原理）の左辺から右辺の含意 だけが意味される，だがここでは，逆方向の含意はトリヴィアルであること (Rami (2009: 4))，また，TMの概念はもともと「実在による真理の決定」「真 理に対する実在の優先性」といつた考えを前提していることに鑑み, TM原理 を本文中のように理解した.

8. 代表的な全面主義者には, Armstrong (2004), Molnar (2000) などがいる.

9. ただしArmstrong (2004: ch.7-8) はこの無謀とも思える試みに挑んでいる.

10. 否定に関する以下の議論では, 特にDodd (2007), Molnar (2000) を参照した.

11.「非全面主義」は一切のTM原理を斥ける立場ではないことに注意せよ.

12. Cf. Mulligan et al. (1984), Simons (1992). ここで, 全面主義の困難に応じるた め, TM原理を制限するのではなく, TM原理の一切のバージョンを捨てて「存 在者の違いなしに真理の違いはない」という付随性テーゼに乗り換える道があ ると思われるかもしれない。 だが，その方針に対する説得的な反論は，Dodd (2007: 394-5), Rodriguez-Pereyra (2005: 19) などにある.

13.この理由はArmstrong (2004: 55), Dodd (2007: 393-4) においても拒否されてい る.

14. 論理語の表象機能に反対する議論は, 野矢 (2002: 89ff.) を参考にした.

15. Cf. Armstrong (2004: 16-7).

16. 主として分量の都合で本文では触れなかつたが, 非全面主義のための他の理 由として，全面主義の不経済性を指摘するものもある（Simons（1992: 161ff.)). だがこの理由に対しては, Cameron (forthcoming: §5）に説得的な応 答がある.

17. 以上の議論に対しては, 複数量化を用いてTM原理を定式化し直すという回 避策があり得るが，すぐ後で見る否定のケースではその策も有効でない.

18. この考えは, Armstrong (2004: 18), Simons (1992: 165) でも触れられている.

19. Cameron (2008: §5) には, 以下の議論への可能な応答と見なせる叙述があ 
る. 同論文で彼は, W型全面主義をとつた場合, 世界の de re 可能性が極端に狭 まるとしても，世界の de dicto可能性が同様に狭まる訳ではないのだから問題 はない, と論じる. だが以下の本文で見るように, 前者の帰結はすでに十分受 け入れ難い.

20. ここでの議論は, 現実世界@をいかなるものとして（e.g. 現実に真である命 題の総体として）考えるかには依存していない. また, ここでは対応者理論を 前提して論じたが，議論の本質的な点は対応者理論にも依存していない。ここ で本質的な仮定は，現実世界がもつdere 可能性について問うことが意味をな す，ということだけである. なお，これら補足の必要性を指摘してくれた点 で，匿名の査読者に感謝したい.

21. 非全面主義の動機づけについてのこうした疑念は, Dodd (2007: 393-4) にも ある.

22. 真理と実在についてのこうした描像をより具体的に展開するためには，なお 二つの重要な課題がある. 第一に, 真理関数的でない結合子 (e.g. 'because' や'after’）を含んだ命題が，いかにして原子命題の真理から説明されるのかを 示す必要がある (cf. Simons (1992))。第二に, 論理語を含んでいないという意 味では原子的な真理が, なお他の真理によって「構成的に (constitutively)」説 明される, というケースを考慮する必要がある（例えば, 色についての命題 は, 物体や知覚者についての極めて複雑な真理から説明されるものであり得 る).これらの課題の検討は他日を期したい.

23. 本稿は，2010年11月27－8日に大阪市立大学で開催された日本科学哲学会第 43回大会での口頭発表の内容に基づいている. 同発表に有益なコメントをくれ た方々, そして本誌の匿名の査読者に感謝したい. なお本稿は, 平成 $22-23$ 年 度科研費（特別研究員奨励費）に基づく研究の成果の一部である.

\section{参考文献}

Armstrong, D.M. (2004) Truth and Truthmakers, Cambridge UP.

Cameron, R. (2008) 'How to be a Truthmaker Maximalist', Nô̂s 42 (3):410-421.

Cameron, R. (forthcoming) 'Truthmakers', in M. Glanzberg (ed.) The Oxford Handbook of Truth, Oxford UP.

Dodd, J. (2007) 'Negative Truths and Truthmaker Principles', Synthese 156 (2):383401.

Molnar, G. (2000) 'Truthmakers for Negative Truths', Australasian Journal of Philosophy 78 (1):72-86.

Mulligan, K., Simons, P., Smith, B. (1984) 'Truth-makers', Philosophy and Phenomenological Research 44 (3):287-321.

Rami, A. (2009) 'Introduction', in A.Rami \& E.J. Lowe (eds.) Truth and Truth-making, McGill-Queen's: 1-36. 
Rodriguez-Pereyra, G. (2005) 'Why Truthmakers', in H. Beebee \& J. Dodd (eds.), Truthmakers: the contemporary debate. Oxford UP: 17-31.

Simons, P. (1992) 'Logical Atomism and its Ontological Refinement: A Defense', in K. Mulligan (ed.) Language, Truth and Ontology, Kluwer: 157-79.

Wittgenstein, L. (1922) Tractatus Logico-Philosophicus, Routledge.

野矢茂樹（2002）『ウィトゲンシュタイン『論理哲学論考』を読む』, 哲学書房. (埼玉大学・日本学術振興会特別研究員 PD) 